Menoufia J. Food \& Dairy Sci., Vol. 6 Oct. (2021): 21-31 https://mjfds.journals.ekb.eg

\title{
UTILIZATION OF SOME PLANT MATERIAL EXTRACTS TO EXTEND THE SHELF LIFE OF CUPCAKES DURING STORAGE
}

\author{
Eman A. Wahba, T. A. El-Adawy, Amal A. Atef and A. E. El-Beltagy \\ Food Science and Technology Department, Faculty of Agriculture, Menoufia University, \\ 32516-Shibin El-Kom, Egypt
}

Received: Sep. 22, 2021

Accepted: Oct. 4, 2021

\begin{abstract}
Natural bioactive compounds (antioxidants and antimicrobials) of three different plant materials (guava leaves, pomegranate peels, and turmeric powder) were extracted by different solvents (water, ethanol $70 \%$, and ethyl acetate). The best plant extracts having high antioxidant activity were added to the cupcake blends to extend its shelf life. Cupcakes containing plant extracts were evaluated during storage for 28 days at room temperature $\left(25 \pm 2^{\circ} \mathrm{C}\right)$ through determination their chemical, microbiological, and sensory properties. The results indicated that ethanol $70 \%$ extracts of both guava leaves at concentration $10 \mathrm{mg} / \mathrm{ml}$ and pomegranate peels at concentration $40 \mathrm{mg} / \mathrm{ml}$ as well as ethyl acetate extracts of turmeric powder at concentration $20 \mathrm{mg} / \mathrm{ml}$ had higher antioxidant activity than other extracts were added to the cupcake blends at concentration $0.5 \%$. The cupcake with pomegranate peel ethanol extract had a lower $(p \leq 0.05)$ means of acid value $(2.85 \mathrm{mg} \mathrm{KOH} / \mathrm{gm}$ oil), thiobarbituric acid value $(0.45 \mathrm{mg}$ malonldhydel $\mathrm{kg}$ sample), and peroxide value ( $3.41 \mathrm{meq}_{2} \mathrm{l} \mathrm{kg}$ oil) than other cupcake samples. Cupcakes with different plant extracts had a lower $(p \leq 0.05)$ means for total bacterial and coliform bacterial counts. Cupcake with pomegranate peel ethanol extract and cupcake with turmeric powder ethyl acetate extract had a lower $(p \leq 0.05)$ means for yeast and mold counts, while cupcake control sample had a highest $(p \leq 0.05)$ means of all microbiological examinations. The values of chemical and microbiological examinations for all cupcake samples at zero time of storage at room temperature were similar then were increased gradually with increasing the storage period. Cupcake control had a lowest $(p \leq 0.05)$ means in all sensory properties than other cupcakes with different plant materials extracts. No differences $(p \geq 0.05)$ were observed among all cupcake samples with different plant material extracts in their sensory properties except colour, and overall acceptability for cupcake samples with turmeric powder extract and $\alpha$-tocopherol.
\end{abstract}

Key words: Cupcakes, plant extracts, Guava leaves, pomegranate peels, turmeric, shelf life, chemical characteristics, microbiological analysis and sensory properties.

\section{INTRODUCTION}

The cake product is one of the most popular bakery items consumed in all over the world because of its nutritional value, different varieties, and affordable price (Sabouri et al., 2012). It has a special texture and its main ingredients are wheat flour, margarine, eggs, sugar, and baking powder (Asimah et al., 2016). The cupcake is a small cake made using special molds and is important for some reasons such as ease of production, portability, the possibility of preparing in batch systems, decorating strategies, and variety of flavours (Jeyanthi Rebecca et al., 2016). Lipid oxidation and mold growth are major problems in producing cake, which limits the shelf life of this product. The onset rancidity in bakery products causes a great influence on organoleptic parameters and losses the nutritional value (Sabouri et al., 2012). These problems may be prevented by the use of antioxidants and preservatives 
Eman A. Wahba, et al.,

(Khaki et al., 2012). The use of synthetic antioxidants has to be limited due to their toxicity, liver damage, and carcinogenicity. Therefore, the development and use of safer antioxidants from natural sources are of interest because of the possible negative effects of synthetic food additives on human health (Nanditha et al., 2009). Plant extracts are containing natural phytochemical components, which have numerous medicinal properties and a wide spectrum of biological actions which include; antioxidant, antiinflammatory, antimutagenic, antidiabetic, anticarcinogenic, anticoagulant, (Fischer et al., 2011; Fernandes et al., 2014; Sandhir et al., 2015; El-Amin et al. 2016; Andrade et al., 2019). Mahmoudi et al. (2020) reported that the cakecontaining butcher broom had lower values of peroxide, thiobarbituric acid, total bacterial count, yeast, and mold counts than the control sample. Sabouri et al. (2012) reported that cakes containing different concentrations of Echinacea purpurea methanolic extract had lower acidity values and prevented mold growth as well as decreased the production of hydrolytic enzymes. Hafez (2012) indicated that using marjoram in cake decreases the thiobarbituric acid value and peroxide value compared to the control sample throughout the storage period at room temperature for 21 days. Therefore, the present study aimed to characterize and the utilization of different plant extracts as a source of antioxidants and antimicrobials to extend the shelf life of cupcakes during storage at room temperature for 28 days.

\section{MATERIALS AND METHODS}

\section{Materials:}

\subsection{Plant materials:}

Turmeric powder (Curcuma longa) and pomegranate fruits (Punica granatum) were purchased from the local market at Shibin El-Kom City, Menoufia Governorate, Egypt. Guava leaves (Psidium guajava) were obtained from a farm at Sokaria Village, Menoufia Governorate, Egypt.

\subsection{Cupcake ingredients:}

Sugar powder, salt, whole egg, wheat flour (72\% extraction), baking powder, vanilla, margarine, and milk were obtained from the local market at Shibin El-Kom City, Menoufia Governorate, Egypt.

\subsection{Chemicals and reagents:}

Ethyl acetate, petroleum ether, ethanol, methanol, chloroform, hexane, diethyl ether, glacial acetic acid, potassium iodide, potassium hydroxide, phenolphthalein, 2,2-diphenyl-1picrylhydrazyl (DPPH), sodium chloride, nutrient broth medium, nutrient agar medium, MacConkey agar medium, potato dextrose agar medium, and sodium thiosulphate were obtained from El-Nasr Pharmaceutical Chemicals, Ameriea, Cairo, Egypt. a-tocopherol was obtained from Sigma Chemical Co., St. Louis, MO, USA.

\section{Methods:}

\subsection{Preparation of plant materials:}

The fresh leaves of guava were washed with tap water to remove debris and completely dried in a shaded place at room temperature $\left(\sim 25 \pm 2^{\circ} \quad C\right)$. Pomegranate fruit having no visible external cuts or spoilage was washed and peels were separated manually then dried in an electric oven (FN500, Germany) overnight $(\sim 18 \mathrm{hr})$ at $40^{\circ} \mathrm{C}$. Both dried guava leaves and pomegranate peels were ground by using an electric mill (Moulinex, LM207, France), then sieved in $0.5 \mathrm{~mm}$ sieve. Guava leaves, pomegranate peels, and turmeric powders were stored in a deep- 
freezer (W. ALASKA, CH 200, Egypt) at $18^{\circ} \mathrm{C}$ in tightly closed high density polyethylene bags for further studies.

\subsection{Extraction of antioxidant and antimicrobial substances:}

Antioxidant and antimicrobial substances of pomegranate peels, guava leaves and turmeric powders were extracted by using different solvents (water, $70 \%$ ethanol, and ethyl acetate) at a ratio of 1:10 (w/v). The mixtures were kept at room temperature $\left(\sim 25 \pm 2^{\circ} \mathrm{C}\right)$ overnight $(\sim 18 \mathrm{hr})$ then filtrated through Whatman No.2 filter paper. The extracts were concentrated by using a rotary evaporator (ACCULAB RE3018, USA) at $45^{\circ} \mathrm{C}$, then evaporated the trace solvent by using a vacuum oven (SPT-200, vacuum- drier, Poland) at $40^{\circ} \mathrm{C}$ for $2 \mathrm{hr}$. The residue was resolved in less amount of distilled water then stored in tightly closed plastic tubes $(50 \mathrm{ml})$ and kept in a freezer (W. ALASKA, CH200, Egypt) at $18^{\circ} \mathrm{C}$ until use.

\subsection{Preparation of cupcakes:}

Cupcakes were prepared according to the procedure of Lu et al. (2010) using the following formula; $29.94 \%$ wheat flour (72\% extraction), $25.44 \%$ sugar, $29.94 \%$ margarine, $0.60 \%$ baking powder, $7.49 \%$ beaten eggs, $5.99 \%$ milk, and $0.60 \%$ vanilla. The whole egg was poured into a mixer bowl (Braun, combimax700, Germany) and mixed for 2 min with vanilla. The total mixing time was $10 \mathrm{~min}$, which consisted of three stages. At the initial stage, sugar and margarine were mixed for 6 min followed by the addition of sifted wheat flour with baking powder and mixed for $30 \mathrm{sec}$ with gradual incorporation of milk containing antioxidant extracts. Finally, ingredients were mixed by hand with a plastic scraper until smooth. The homogeneous blend was divided into five blends, and each blend was well mixed with one of the following materials: blend-1 contained $50 \mathrm{ppm}$ guava ethanol extract/ gm blend, blend-2 contained 200 ppm pomegranate ethanol extract/ gm blend, blend-3 contained 100 ppm turmeric ethyl acetate extract/ gm blend, blend-4 contained $10 \mathrm{ppm}$ a-tocopheroll gm blend as a reference sample, and lastly, and blend-5 is free from any additives (control). For each cupcake, $-50 \mathrm{gm}$ of batter were weighed and placed in paper baking cups in an aluminum muffin pan, then baked at $160^{\circ} \mathrm{C}$ for $30 \mathrm{~min}$ in a preheated electric baking oven (SHARB, EO-42K-2, Japan). Cupcakes were cooled to room temperature $\left(25^{\circ} \mathrm{C} \pm 2^{\circ} \mathrm{C}\right)$ then packed in polypropylene films to prevent drying and stored at room temperature. Cupcakes were served after cooling to room temperature ( $2 \mathrm{hr}$ after baking) and every seven days of storage until their sensory properties were deteriorated.

\subsection{Chemical analysis:}

Antioxidant activity was determined using the 2, 2-diphenyl-1- picrylhydrazyl (DPPH) radical scavenging method according to the procedure described by Brand-Williams et al. (1995). The peroxide value (PV) and acid value (AV) were determined according to AOAC (2005). Thiobarbituric acid (TBA) value was determined according to the method of Sidwell et al. (1954).

\subsection{Microbiological analysis:}

\subsubsection{Sample preparation for microbiological examinations:}

Ten grams of each sample were mixed with $90 \mathrm{ml}$ of sterile saline solution (9 gm $\mathrm{NaCl}$ l distilled water) in a blender, under aseptic conditions, to give 1/ 10 dilution. Serial dilutions were prepared to be used for microbiological examination (APHA, 1976). 
Eman A. Wahba, et al.,

\subsubsection{Microbiological examinations}

The total aerobic bacteria counts were determined using nutrient agar medium and the coliform bacteria were determined using MacConkey agar medium according to the procedure described by APHA (1976). The procedures of Difco (1984) were followed for the determination of yeast and mold counts using potato-dextrose agar medium.

\subsection{Sensory properties:}

Sensory evaluations of cupcakes were performed by 10 panelists of staff members of the Food Science and Technology Department, Faculty of Agriculture, Menoufia University. Panelists were selected basis on their interests and availability. Sensory quality properties were evaluated using a 7point hedonic rating scale with 1 for dislike extremely to 7 for like extremely for each property as described by EIAdawy (1997). Randomly coded samples were served to panelists individually. Panelists evaluated cupcake samples which were offered at the same time in a specific area of the sensory test without special lighting. Water was provided for rinsing purposes. Cupcakes were evaluated for appearance, colour, odour, taste, texture and overall acceptability.

\subsection{Statistical analysis:}

Statistical analysis was conducted according to Snedecor and Cochran (1994). Results of microbiological analysis and chemical properties of cupcakes are expressed as the mean value \pm SD of three separate determinations. Sensory properties of cupcakes were determined as the mean of ten replicates. Two-way (Factorial Design) analysis of variance was used for the data. The least significant difference (LSD) was used for comparison among means, considering significance at $0.05 \%$ level, using Costat version 6.311 (Copyright 1998-2005, CoHort software).

\section{RESULTS AND DISCUSSION}

\section{Chemical analysis:}

The results showed that $70 \%$ ethanol extracts of both guava leaves at concentration $10 \mathrm{mgl} \mathrm{ml}$ and pomegranate peels at concentration 40 $\mathrm{mg} / \mathrm{ml}$ as well as ethyl acetate extracts of turmeric powder at concentration 20 $\mathrm{mg} / \mathrm{ml}$ had the higher antioxidant activity (92.30 94.06, and $96.20 \%$, respectively) than other extracts. Therefore, the previous plant extracts that have highly antioxidant activity were added to the cupcake blends at concentration $0.5 \%$.

The acid value (AV), thiobarbituric acid value (TBA), and peroxide acid (PV) results of cupcake samples as affected by plant material extracts addition and storage period at room temperature are presented in Table (1). The AV, TBA, and PV were affected ( $p \leq 0.05$ ) by storage period and plant material extract types. The cupcake control sample had a higher ( $p \leq 0.05)$ means AV (4.21 $\mathrm{mg} \mathrm{KOH} / \mathrm{gm}$ oil), TBA (0.67 $\mathrm{mg}$ malonldhydel $\mathrm{kg}$ sample), and PV (6.52 meq $\mathrm{O}_{2} \mathrm{l} \mathrm{kg}$ oil) than other cupcake samples, while the cupcake with pomegranate peel ethanol extract had a lower ( $p \leq 0.05$ ) means AV (2.85 mg KOH/ gm oil), TBA (0.45 mg malonldhydel $\mathrm{kg} \mathrm{oil}$ ), and PV (3.41 meq $\mathrm{O}_{2} / \mathrm{kg}$ oil of active oxygen/ $\mathrm{kg}$ oil) than other cupcake samples. The AV, TBA, and PV means were gradually ( $p \leq 0.05$ ) increased in all cupcake samples with increasing the storage period. The results of acid values, TBA values, and peroxide values for all cupcake samples at the beginning of storage period were almost the same (1.23 $\mathrm{mg} \mathrm{KOH} / \mathrm{gm}$ oil, $0.24 \mathrm{mg}$ malonldhydel $\mathrm{kg}$ oil, and $\mathbf{1 . 4 4}$ meq $\mathrm{O}_{2} / \mathrm{kg}$ oil of active oxygen/ $\mathrm{kg}$ oil, respectively) and these result are in agreement with Kozłowska et al. (2019) 
for acid values, Mahmoudi et al. (2020) for TBA and PV values. Sabouri et al. (2012) reported that cakes containing different concentrations of Echinacea purpurea methanolic extract had lower acid values, TBA value, and PV than the control sample during storage at room temperature. Kordsardouei et al. (2013) reported that the increase of $A V$, TBA value, and $P V$ during storage at room temperature was higher in control cakes than the cake samples containing
Cinnamon zeylanicum essential oils, Zataria multiflora Boiss and BHA. Kozłowska et al. (2019) reported that the acid values of all treated cake samples (control, BHA, and green tea aqueous extract) after baking were similar (0.24 $\mathrm{mg} \mathrm{KOH} / \mathrm{gm}$ of fat), then increased gradually up to the end of the storage time after 28 days for all the samples, but the highest acid value was found for the control sample.

Table (1): Changes in chemical properties of cupcakes as affected by plant material extracts addition and storage period at room temperature.

\begin{tabular}{|c|c|c|c|c|c|c|}
\hline \multirow{2}{*}{ cupcake blends } & \multicolumn{5}{|c|}{ Storage period (Days) } & \multirow{2}{*}{ Means $^{1}$} \\
\hline & 0 & 7 & 14 & 21 & 28 & \\
\hline \multicolumn{7}{|l|}{ Acid value (mg KOH/ gm oil) } \\
\hline Control $(0.0)$ & $1.23 \pm 0.13$ & $2.23 \pm 0.09$ & $4.53 \pm 0.44$ & $5.87 \pm 0.31$ & $7.21 \pm 0.59$ & $4.21^{\mathrm{a}}$ \\
\hline a-tocopherol, $10 \mathrm{ppm} / \mathrm{gm}$ blend & $1.23 \pm 0.13$ & $2.05 \pm 0.27$ & $3.45 \pm 0.29$ & $3.99 \pm 0.64$ & $5.34 \pm 0.25$ & $3.21^{b}$ \\
\hline $\begin{array}{l}\text { Guava leaves ethanol extract, } 50 \\
\mathrm{ppm} / \mathrm{gm} \text { blend }\end{array}$ & $1.23 \pm 0.13$ & $2.05 \pm 0.10$ & $3.60 \pm 0.15$ & $4.54 \pm 0.44$ & $5.45 \pm 0.28$ & $3.37^{\mathrm{b}}$ \\
\hline $\begin{array}{l}\text { Turmeric powder ethyl acetate } \\
\text { extract,100 ppm/ gm blend }\end{array}$ & $1.23 \pm 0.13$ & $2.12 \pm 0.07$ & $3.49 \pm 0.25$ & $3.89 \pm 0.20$ & $5.29 \pm 0.14$ & $3.20^{\mathrm{b}}$ \\
\hline $\begin{array}{l}\text { Pomegranate peels ethanol extract, } \\
200 \mathrm{ppm} / \mathrm{gm} \text { blend }\end{array}$ & $1.23 \pm 0.13$ & $1.85 \pm 0.12$ & $2.66 \pm 0.44$ & $3.68 \pm 0.28$ & $4.84 \pm 0.22$ & $2.85^{c}$ \\
\hline Mean $^{2}$ & $1.23^{\mathrm{e}}$ & $2.06^{d}$ & $3.54^{c}$ & $4.39^{b}$ & $5.62^{\mathrm{a}}$ & \\
\hline \multicolumn{7}{|c|}{ Thiobarbituric acid value (mg malonldhyde/ kg oil) } \\
\hline Control (0.0) & $0.24 \pm 0.03$ & $0.50 \pm 0.02$ & $0.69 \pm 0.02$ & $0.79 \pm 0.02$ & $1.13 \pm 0.15$ & $0.67^{a}$ \\
\hline a-tocopherol, $10 \mathrm{ppm} / \mathrm{gm}$ blend & $0.24 \pm 0.03$ & $0.45 \pm 0.03$ & $0.51 \pm 0.01$ & $0.60 \pm 0.02$ & $0.79 \pm 0.03$ & $0.52^{b}$ \\
\hline $\begin{array}{l}\text { Guava leaves ethanol extract, } 50 \\
\mathrm{ppm} / \mathrm{gm} \text { blend }\end{array}$ & $0.24 \pm 0.03$ & $0.42 \pm 0.03$ & $0.51 \pm 0.01$ & $0.56 \pm 0.02$ & $0.71 \pm 0.02$ & $0.49^{b}$ \\
\hline $\begin{array}{l}\text { Turmeric powder ethyl acetate } \\
\text { extract,100 ppm/ gm blend }\end{array}$ & $0.24 \pm 0.03$ & $0.44 \pm 0.02$ & $0.51 \pm 0.02$ & $0.59 \pm 0.01$ & $0.73 \pm 0.03$ & $0.50^{\mathrm{b}}$ \\
\hline $\begin{array}{l}\text { Pomegranate peels ethanol extract, } \\
200 \mathrm{ppm} / \mathrm{gm} \text { blend }\end{array}$ & $0.24 \pm 0.03$ & $0.40 \pm 0.02$ & $0.49 \pm 0.02$ & $0.53 \pm 0.04$ & $0.61 \pm 0.02$ & $0.45^{c}$ \\
\hline Mean $^{2}$ & $0.24^{e}$ & $0.442^{\mathrm{d}}$ & $0.542^{c}$ & $0.613^{b}$ & $0.795^{a}$ & \\
\hline \multicolumn{7}{|l|}{ Peroxide value (meq $\mathrm{O}_{2} / \mathrm{kg}$ oil) } \\
\hline Control $(0.0)$ & $1.44 \pm 0.16$ & $3.61 \pm 0.22$ & $7.57 \pm 0.32$ & $8.87 \pm 0.22$ & $11.13 \pm 0.5$ & $6.52^{\mathrm{a}}$ \\
\hline a-tocopherol, 10 ppm/ gm blend & $1.44 \pm 0.16$ & $2.51 \pm 0.32$ & $3.75 \pm 0.69$ & $5.10 \pm 0.35$ & $6.67 \pm 0.60$ & $3.89^{b}$ \\
\hline $\begin{array}{l}\text { Guava leaves ethanol extract, } 50 \\
\mathrm{ppm} / \mathrm{gm} \text { blend }\end{array}$ & $1.44 \pm 0.16$ & $2.27 \pm 0.22$ & $4.49 \pm 0.26$ & $5.41 \pm 0.39$ & $6.42 \pm 1.10$ & $4.003^{b}$ \\
\hline $\begin{array}{l}\text { Turmeric powder ethyl acetate } \\
\text { extract,100 ppm/ gm blend }\end{array}$ & $1.44 \pm 0.16$ & $2.76 \pm 0.02$ & $3.58 \pm 0.08$ & $5.07 \pm 0.36$ & $6.09 \pm 0.31$ & $3.79^{b}$ \\
\hline $\begin{array}{l}\text { Pomegranate peels ethanol extract, } \\
200 \mathrm{ppm} / \mathrm{gm} \text { blend }\end{array}$ & $1.44 \pm 0.16$ & $2.05 \pm 0.55$ & $3.48 \pm 0.25$ & $4.58 \pm 0.15$ & $5.49 \pm 0.74$ & $3.41^{c}$ \\
\hline Mean $^{2}$ & $1.44^{e}$ & $2.64^{d}$ & $4.57^{\mathrm{c}}$ & $5.81^{b}$ & $7.16^{\mathrm{a}}$ & \\
\hline
\end{tabular}

${ }^{1}$ Means in the same column with different letters are significantly different $(p \leq 0.05)$, LSD $=0.22$, 0.28 , and 0.31 for of acid value, thiobarbituric acid value, and peroxide value, respectively.

${ }^{2}$ Means in the same row with different letters are significantly different $(p \leq 0.05)$, LSD $=0.22,0.28$, and 0.31 for acid value, thiobarbituric acid value, and peroxide value, respectively. 


\section{Microbiological analysis:}

Total aerobic bacterial count, coliform bacteria, and yeast \& mold count results of cupcake samples as affected by added plant material extracts and storage period at room temperature are presented in Table (2). The total aerobic bacterial count, coliform bacteria, and yeast \& mold count was affected ( $p \leq$ 0.05 ) by storage period and plant material extract types. The cupcake control sample had a higher ( $p \leq 0.05)$ means total aerobic bacterial count (5.37 log CFUl gm sample), yeast \& mold count (2.34 log CFUl gm sample), and coliform bacterial count (1.28 log CFUl gm sample), while cupcakes with different plant material extracts had a lower means total aerobic bacterial count and coliform bacterial count. Cupcake with pomegranate peel ethanol extract and cupcake with turmeric powder ethyl acetate extract had a lower means yeast $\&$ mold count (1.65 and $1.76 \log$ CFU/ gm sample, respectively). The total aerobic bacterial count, coliform bacterial, and yeast $\&$ mold means were gradually ( $p \leq$ 0.05 ) increased in all cupcake samples with increasing the storage period. Total aerobic bacterial count, and yeast \& mold means of all cupcake samples at zero time of storage period was completely absent, while; coliform bacterial count means of all cupcake samples at zero and after 7 days was absent and that in agreement with Khalifa et al. (2015), who reported that a coliform bacterium wasn't detected in all cupcakes during storage period at room temperature for 8 days, while yeast and mold count was zero at the beginning of the storage period. The cupcake control sample results at the end of storage after 28 days (9.70 log CFU/ gm) were higher than that reported by Mahmoudi et al. (2020), who reported that the total bacterial count of the control cake sample increased with a sharp slope until the end of the storage period. While it was increased with a lower slope in the cake with butcher broom extracts in pure-water, ethanol $50 \%$ and pure-ethanol as well as butcher broom nano-capsulation in the first day of storage.

\section{Sensory evaluation:}

Table (3) summarizes the results of sensory properties of cupcake samples as affected by plant material extracts addition and storage at room temperature. All sensory properties were affected $(p \leq 0.05)$ by the storage period at room temperature and plant material extract types. Cupcake control had a lower ( $p \leq 0.05$ ) means in all sensory properties than other cupcakes with different plant materials extracts. No ( $p \geq$ 0.05 ) differences were observed among all cupcake samples with different plant material extracts in their sensory properties except appearance for cupcake sample with $\alpha$-tocopherol, colour, and overall acceptability for cupcake samples with turmeric powder extract and $\alpha$-tocopherol. All sensory properties mean of all cupcake samples were gradually ( $p \leq 0.05$ ) decreased with the increase of storage period. Appearance and taste of all cupcake samples were affected ( $p \leq 0.05)$ after 14 days of storage period, while the other sensory properties were affected after $7^{\text {th }}$ days of the storage period. Sabouri et al. (2012) reported that the cakes containing 1000 and $1500 \mathrm{ppm}$ of Echinacea purpurea methanolic extract had better colour, taste, texture, and total acceptability in comparison with those prepared with synthetic antioxidants. Khaki et al. (2012) showed that the cake sample containing chamomile essential oil at concentration $0.05 \%$ had a higher score in flavour, taste, and overall acceptability than the samples at 0.15 and $0.1 \%$. Ibrahium et al. (2013) reported that there are no differences among cake 
samples containing BHT or clove essential oil at different levels in appearance, colour, and texture. Mahmoud et al. (2016) reported that the appearance of all cake samples was not affected before or after the addition of synthetic, natural, or nano-encapsulated nature antioxidants of lemon and orange peel extracts. Senanayake et al. (2018) reported that sensory scores of cake samples containing Psidium guineense Sw leaves ethanol extracts at 200 ppm do not cause any negative sensory impacts. Senanayake et al. (2019) reported that most sensory scores for all the cake samples containing coconut oil meal ethanol extract, sesame oil meal ethanol extract, and BHT are significantly high on day 1 compared with later dates.

Table (2): Changes in microbiological properties of cupcakes as affected by plant material extracts addition and storage period at room temperature.

\begin{tabular}{|c|c|c|c|c|c|c|}
\hline \multirow{2}{*}{ cupcake blends } & \multicolumn{5}{|c|}{ Storage period (Days) } & \multirow{2}{*}{ Means $^{1}$} \\
\hline & 0 & 7 & 14 & 21 & 28 & \\
\hline \multicolumn{7}{|c|}{ Total aerobic bacterial count (log CFU/ gm sample) } \\
\hline Control (0.0) & 0 & $3.70 \pm 0.36$ & $5.50 \pm 0.60$ & $7.96 \pm 0.40$ & $9.70 \pm 0.36$ & $5.37^{\mathrm{a}}$ \\
\hline$\alpha$-tocopherol, $10 \mathrm{ppm} / \mathrm{gm}$ blend & 0 & $3.60 \pm 0.45$ & $4.60 \pm 0.26$ & $6.70 \pm 0.43$ & $8.40 \pm 0.45$ & $4.66^{b}$ \\
\hline $\begin{array}{l}\text { Guava leaves ethanol extract, } 50 \mathrm{ppm} / \\
\text { gm blend }\end{array}$ & 0 & $3.46 \pm 0.20$ & $4.16 \pm 0.25$ & $6.26 \pm 0.45$ & $8.23 \pm 0.41$ & $4.42^{\mathrm{bc}}$ \\
\hline $\begin{array}{l}\text { Turmeric powder ethyl acetate } \\
\text { extract,100 ppm/ gm blend }\end{array}$ & 0 & $3.40 \pm 0.52$ & $4.36 \pm 1.01$ & $5.93 \pm 0.32$ & $7.63 \pm 0.41$ & $4.26^{c}$ \\
\hline $\begin{array}{l}\text { Pomegranate peels ethanol extract, } 200 \\
\text { ppm/ gm blend }\end{array}$ & 0 & $3.13 \pm 0.40$ & $4.13 \pm 0.65$ & $5.76 \pm 0.21$ & $7.56 \pm 0.25$ & $4.12^{\mathrm{c}}$ \\
\hline Mean $^{2}$ & $0^{\mathrm{e}}$ & $3.46^{d}$ & $4.55^{c}$ & $6.52^{b}$ & $8.30^{\mathrm{a}}$ & \\
\hline \multicolumn{7}{|c|}{ Coliform bacterial count (log CFU/ gm sample) } \\
\hline Control (0.0) & 0 & 0 & $1.86 \pm 0.32$ & $2.1 \pm 0.36$ & $2.73 \pm 0.21$ & $1.34^{\mathrm{a}}$ \\
\hline a-tocopherol, $10 \mathrm{ppm} / \mathrm{gm}$ blend & 0 & 0 & $1.80 \pm 0.26$ & $2.06 \pm 0.15$ & $2.56 \pm 0.23$ & $1.28^{a}$ \\
\hline $\begin{array}{l}\text { Guava leaves ethanol extract, } 50 \text { ppm/ } \\
\text { gm blend }\end{array}$ & 0 & 0 & $1.63 \pm 0.15$ & $1.83 \pm 0.05$ & $2.16 \pm 0.21$ & $1.12^{\mathrm{b}}$ \\
\hline $\begin{array}{l}\text { Turmeric powder ethyl acetate } \\
\text { extract,100 ppm/ gm blend }\end{array}$ & 0 & 0 & $1.66 \pm 0.30$ & $1.76 \pm 0.50$ & $2.03 \pm 0.15$ & $1.09^{b}$ \\
\hline $\begin{array}{l}\text { Pomegranate peels ethanol extract, } 200 \\
\mathrm{ppm} / \text { gm blend }\end{array}$ & 0 & 0 & $1.53 \pm 0.35$ & $1.73 \pm 0.15$ & $1.96 \pm 0.15$ & $1.04^{b}$ \\
\hline Mean $^{2}$ & $0^{d}$ & $0^{d}$ & $1.70^{\mathrm{c}}$ & $1.90^{b}$ & $2.29^{a}$ & \\
\hline \multicolumn{7}{|l|}{ Yeast and mold count (log CFU/ gm sample) } \\
\hline Control (0.0) & 0 & $2.13 \pm 0.21$ & $2.53 \pm 0.25$ & $3.03 \pm 0.20$ & $4 \pm 0.45$ & $2.34^{a}$ \\
\hline a-tocopherol, 10 ppm/ gm blend & 0 & $2.03 \pm 0.25$ & $2.3 \pm 0.20$ & $2.76 \pm 0.25$ & $3.53 \pm 0.45$ & $2.12^{b}$ \\
\hline $\begin{array}{l}\text { Guava leaves ethanol extract, } 50 \mathrm{ppm} / \\
\text { gm blend }\end{array}$ & 0 & $1.96 \pm 0.30$ & $2.26 \pm 0.20$ & $2.36 \pm 0.25$ & $2.93 \pm 0.32$ & $1.90^{\mathrm{c}}$ \\
\hline $\begin{array}{l}\text { Turmeric powder ethyl acetate } \\
\text { extract,100 ppm/ gm blend }\end{array}$ & 0 & $1.66 \pm 0.15$ & $1.93 \pm 0.15$ & $2.50 \pm 0.43$ & $2.70 \pm 0.43$ & $1.76^{\mathrm{cd}}$ \\
\hline $\begin{array}{l}\text { Pomegranate peels ethanol extract, } 200 \\
\mathrm{ppm} / \mathrm{gm} \text { blend }\end{array}$ & 0 & $1.60 \pm 0.20$ & $1.86 \pm 0.15$ & $2.23 \pm 0.32$ & $2.56 \pm 0.20$ & $1.65^{d}$ \\
\hline Mean $^{2}$ & $\mathbf{0}^{\mathrm{e}}$ & \begin{tabular}{|l|l}
$1.88^{d}$ \\
\end{tabular} & $2.18^{c}$ & $2.58^{b}$ & $3.14^{\mathrm{a}}$ & \\
\hline \multicolumn{7}{|c|}{$\begin{array}{l}1 \text { Means in the same column with different letters are significantly different }(p \leq 0.05) \text {, LSD }=0.31 \text {, } \\
0.14 \text {, and } 0.19 \text { for total aerobic bacterial count, coliform bacterial count, and yeast and mold } \\
\text { count, respectively. } \\
2 \text { Means in the same row with different letters are significantly different ( } p \leq 0.05) \text {, LSD }=0.31,0.14 \text {, } \\
\text { and } 0.19 \text { for total aerobic bacterial count, coliform bacterial count, and yeast and mold count, } \\
\text { respectively. }\end{array}$} \\
\hline
\end{tabular}


Eman A. Wahba, et al.,

Table (3): Changes in sensory properties of cupcakes as affected by plant material extracts addition and storage period at room temperature.

\begin{tabular}{|c|c|c|c|c|c|c|}
\hline \multirow{2}{*}{ cupcake blends } & \multicolumn{5}{|c|}{ Storage period (Days) } & \multirow{2}{*}{ Means $^{1}$} \\
\hline & 0 & \begin{tabular}{l|l}
7 \\
\end{tabular} & 14 & 21 & 28 & \\
\hline \multicolumn{7}{|l|}{ Appearance } \\
\hline Control (0.0) & $6.0 \pm 0.66$ & $5.2 \pm 1.39$ & $4.7 \pm 1.33$ & $3.6 \pm 0.84$ & $2.5 \pm 1.43$ & $4.4^{c}$ \\
\hline a-tocopherol, $10 \mathrm{ppm} / \mathrm{gm}$ blend & $6.7 \pm 0.48$ & $6.5 \pm 0.52$ & $5.2 \pm 1.13$ & $5.5 \pm 0.70$ & $4.4 \pm 1.17$ & $5.66^{a}$ \\
\hline Guava leaves ethanol extract, $50 \mathrm{ppm} / \mathrm{gm}$ blend & $6.0 \pm 0.66$ & $5.4 \pm 0.84$ & $4.7 \pm 1.05$ & $4.9 \pm 0.87$ & $3.8 \pm 1.03$ & $4.96^{b}$ \\
\hline $\begin{array}{l}\text { Turmeric powder ethyl acetate extract,100 ppml } \\
\text { gm blend }\end{array}$ & $6.4 \pm 0.84$ & $6.4 \pm 0.84$ & $5.2 \pm 1.31$ & $5.1 \pm 0.87$ & $3.7 \pm 1.88$ & $5.36^{\mathrm{ab}}$ \\
\hline $\begin{array}{l}\text { Pomegranate peels ethanol extract, } 200 \text { ppm/ } \\
\text { gm blend }\end{array}$ & $5.9 \pm 0.56$ & $5.6 \pm 1.07$ & $5.5 \pm 1.17$ & $4.5 \pm 0.08$ & $3.2 \pm 1.47$ & $4.94^{b}$ \\
\hline Mean $^{2}$ & $6.20^{\mathrm{a}}$ & $5.82^{\mathrm{a}}$ & $5.06^{\mathrm{b}}$ & $4.72^{\mathrm{b}}$ & $3.52^{\mathrm{c}}$ & \\
\hline \multicolumn{7}{|l|}{ Texture } \\
\hline Control (0.0) & $6.2 \pm 0.63$ & $5.3 \pm 1.33$ & $4.8 \pm 1.22$ & $3.9 \pm 1.10$ & $2.3 \pm 1.70$ & $4.50^{\mathrm{b}}$ \\
\hline a-tocopherol, $10 \mathrm{ppm} / \mathrm{gm}$ blend & $6.7 \pm 0.48$ & $6.1 \pm 0.56$ & $5.5 \pm 0.84$ & $5.4 \pm 0.84$ & $4.0 \pm 1.15$ & $5.54^{\mathrm{a}}$ \\
\hline Guava leaves ethanol extract, $50 \mathrm{ppm} / \mathrm{gm}$ blend & $6.5 \pm 0.70$ & $5.0 \pm 1.41$ & $5.2 \pm 1.13$ & $5.1 \pm 0.99$ & $3.7 \pm 1.33$ & $5.10^{\mathrm{a}}$ \\
\hline $\begin{array}{l}\text { Turmeric powder ethyl acetate extract,100 ppm/ } \\
\text { gm blend }\end{array}$ & $6.4 \pm 0.51$ & $5.7 \pm 0.67$ & $5.4 \pm 0.69$ & $4.5 \pm 1.35$ & $4.0 \pm 2.05$ & $5.20^{\mathrm{a}}$ \\
\hline $\begin{array}{l}\text { Pomegranate peels ethanol extract, } 200 \text { ppml } \\
\text { gm blend }\end{array}$ & $6.3 \pm 0.82$ & $5.8 \pm 1.13$ & $5.1 \pm 0.87$ & $5.0 \pm 0.66$ & $3.0 \pm 1.33$ & $5.04^{\mathrm{a}}$ \\
\hline Mean $^{2}$ & $6.42^{\mathrm{a}}$ & $5.58^{\mathrm{b}}$ & $5.20^{\mathrm{b}}$ & $4.78^{c}$ & $3.40^{\mathrm{d}}$ & \\
\hline \multicolumn{7}{|l|}{ Colour } \\
\hline Control $(0.0)$ & $5.5 \pm 0.84$ & $5.2 \pm 1.75$ & $4.7 \pm 1.41$ & $4.6 \pm 0.96$ & $2.0 \pm 1.15$ & $4.4^{\mathrm{b}}$ \\
\hline$\alpha$-tocopherol, $10 \mathrm{ppm} / \mathrm{gm}$ blend & $6.8 \pm 0.42$ & $5.9 \pm 0.73$ & $5.4 \pm 1.34$ & $5.1 \pm 1.28$ & $3.4 \pm 1.64$ & $5.32^{a}$ \\
\hline Guava leaves ethanol extract, $50 \mathrm{ppm} / \mathrm{gm}$ blend & $5.7 \pm 0.82$ & $4.9 \pm 1.37$ & $4.5 \pm 1.35$ & $5.1 \pm 0.87$ & $3.0 \pm 4.63$ & $4.64^{b}$ \\
\hline $\begin{array}{l}\text { Turmeric powder ethyl acetate extract,100 ppml } \\
\text { gm blend }\end{array}$ & $6.5 \pm 0.70$ & $6.2 \pm 0.63$ & $5.4 \pm 1.07$ & $5.3 \pm 0.82$ & $3.7 \pm 1.49$ & $5.42^{\mathrm{a}}$ \\
\hline $\begin{array}{l}\text { Pomegranate peels ethanol extract, } 200 \text { ppml } \\
\text { gm blend }\end{array}$ & $5.7 \pm 0.67$ & $4.6 \pm 0.84$ & $4.6 \pm 1.34$ & $4.5 \pm 0.84$ & $3.4 \pm 1.64$ & $4.56^{b}$ \\
\hline Mean $^{2}$ & $6.04^{a}$ & $5.36^{\mathrm{b}}$ & $4.92^{b}$ & $4.92^{b}$ & $3.10^{\mathrm{c}}$ & \\
\hline \multicolumn{7}{|l|}{ Taste } \\
\hline Control $(0.0)$ & $5.7 \pm 0.82$ & $5.1 \pm 0.99$ & $4.5 \pm 1.26$ & $3.6 \pm 1.07$ & $1.8 \pm 1.31$ & $4.14^{b}$ \\
\hline a-tocopherol, $10 \mathrm{ppm} / \mathrm{gm}$ blend & $5.8 \pm 0.42$ & $6.2 \pm 0.63$ & $5.6 \pm 1.50$ & $4.7 \pm 1.15$ & $3.4 \pm 1.26$ & $5.14^{\mathrm{a}}$ \\
\hline Guava leaves ethanol extract, $50 \mathrm{ppm} / \mathrm{gm}$ blend & $5.5 \pm 0.84$ & $5.4 \pm 1.50$ & $4.5 \pm 1.08$ & $4.7 \pm 1.25$ & $3.3 \pm 1.56$ & $4.68^{\mathrm{a}}$ \\
\hline $\begin{array}{l}\text { Turmeric powder ethyl acetate extract,100 ppm/ } \\
\text { gm blend }\end{array}$ & $5.8 \pm 0.42$ & $5.5 \pm 0.52$ & $5.2 \pm 1.31$ & $5.2 \pm 0.63$ & $3.8 \pm 1.75$ & $5.10^{a}$ \\
\hline $\begin{array}{l}\text { Pomegranate peels ethanol extract, } 200 \text { ppm/ } \\
\text { gm blend }\end{array}$ & $5.6 \pm 0.69$ & $5.2 \pm 0.78$ & $4.9 \pm 0.99$ & $4.8 \pm 0.63$ & $3.0 \pm 1.49$ & $4.70^{\mathrm{a}}$ \\
\hline Mean $^{2}$ & $5.68^{\mathrm{a}}$ & $5.48^{\mathrm{a}}$ & $4.94^{\mathrm{b}}$ & $4.60^{b}$ & $3.06^{\mathrm{c}}$ & \\
\hline \multicolumn{7}{|l|}{ Odour } \\
\hline Control (0.0) & $5.7 \pm 0.48$ & $4.8 \pm 0.78$ & $4.6 \pm 1.07$ & $3.3 \pm 1.15$ & $2.1 \pm 1.10$ & $4.10^{b}$ \\
\hline$\alpha$-tocopherol, $10 \mathrm{ppm} / \mathrm{gm}$ blend & $6.0 \pm 0.81$ & $5.5 \pm 0.70$ & $5.4 \pm 1.34$ & $5.0 \pm 1.24$ & $3.7 \pm 1.33$ & $5.12^{\mathrm{a}}$ \\
\hline Guava leaves ethanol extract, $50 \mathrm{ppm} / \mathrm{gm}$ blend & $6.1 \pm 0.73$ & $5.2 \pm 1.31$ & $4.7 \pm 1.49$ & $4.3 \pm 1.15$ & $3.6 \pm 1.26$ & $4.78^{\mathrm{a}}$ \\
\hline $\begin{array}{l}\text { Turmeric powder ethyl acetate extract,100 ppm/ } \\
\text { gm blend }\end{array}$ & $5.9 \pm 0.73$ & $5.9 \pm 0.99$ & $5.0 \pm 1.05$ & $4.7 \pm 0.67$ & $3.4 \pm 1.77$ & $4.98^{\mathrm{a}}$ \\
\hline $\begin{array}{l}\text { Pomegranate peels ethanol extract, } 200 \text { ppm/ } \\
\text { gm blend }\end{array}$ & $6.2 \pm 0.78$ & $5.4 \pm 1.07$ & $5.0 \pm 1.41$ & $4.4 \pm 1.17$ & $3.3 \pm 1.15$ & $4.86^{\mathrm{a}}$ \\
\hline Mean $^{2}$ & $5.98^{\mathrm{a}}$ & $5.36^{\mathrm{b}}$ & $4.94^{\mathrm{c}}$ & $4.34^{\mathrm{d}}$ & $3.22^{\mathrm{e}}$ & \\
\hline \multicolumn{7}{|l|}{ Over all acceptability } \\
\hline Control $(0.0)$ & $5.64 \pm 0.50$ & $5.14 \pm 1.18$ & $4.66 \pm 1.02$ & $3.82 \pm 0.6$ & $2.18 \pm 1.25$ & $4.28^{\mathrm{c}}$ \\
\hline a-tocopherol, $10 \mathrm{ppm} / \mathrm{gm}$ blend & $6.48 \pm 0.31$ & $6.04 \pm 0.32$ & $5.38 \pm 0.89$ & $4.96 \pm 0.66$ & $3.68 \pm 1.03$ & $5.30^{\mathrm{a}}$ \\
\hline Guava leaves ethanol extract, $50 \mathrm{ppm} / \mathrm{gm}$ blend & $5.82 \pm 0.53$ & $5.18 \pm 1.17$ & $4.68 \pm 0.91$ & $4.80 \pm 0.76$ & $3.48 \pm 1.13$ & $4.79^{b}$ \\
\hline $\begin{array}{l}\text { Turmeric powder ethyl acetate extract,100 ppm/ } \\
\text { gm blend }\end{array}$ & $6.34 \pm 0.29$ & $5.92 \pm 0.54$ & $5.08 \pm 0.81$ & $4.90 \pm 0.42$ & $3.72 \pm 1.51$ & $5.19^{\mathrm{a}}$ \\
\hline $\begin{array}{l}\text { Pomegranate peels ethanol extract, } 200 \text { ppml } \\
\text { gm blend }\end{array}$ & $5.81 \pm 0.53$ & $5.18 \pm 0.71$ & $5.02 \pm 0.76$ & $4.58 \pm 0.50$ & $2.66 \pm 1.32$ & $4.65^{\mathrm{b}}$ \\
\hline Means $^{2}$ & $6.01^{\mathrm{a}}$ & $5.49^{\mathrm{b}}$ & $4.96^{\mathrm{c}}$ & $4.61^{\mathrm{d}}$ & $3.14^{\mathrm{e}}$ & \\
\hline
\end{tabular}




\section{Conclusion}

From previous results, it can be concluded that the control cupcake sample and cupcake samples containing plant material extracts were almost the same in their shelf life, quality characteristics, and consumer acceptance up to 28 days, so the storage period had to be increased to study its effect on the previous properties.

\section{REFERENCES}

Andrade, M. A., V. Lima, A. Sanches Silva, F. Vilarinho, M. C. Castilho, K. Khwaldia and F. Ramos (2019). Pomegranate and grape by-products and their active compounds: Are they a valuable source for food applications. Trends in Food Science and Technology, 86, 68-84.

AOAC (2005). Official Methods of Analysis Association of Official Analytical Chemists International, $19^{\text {th }}$ ed. Maryland, USA.

APHA (1976). American Public Health Association, Compendium of Methods for the Microbiological Examination of Foods. Speck, M. L. ed., Washington D. C., USA.

Asimah, V. K., F. M. Kpodo, O. A. Adzinyo and C. S. Dzah (2016). Utilization of brown rice flour and peanut paste in cake production. American Journal of Food Science and Technology, 4(5):129-134.

Brand-Williams, W., M. E. Cuvelier and C. Berset (1995). Use of a free radical method to evaluate antioxidant activity. Lebensmitttel Wissenschaft und Technologie, 28: 25 - 30.

Difco (1984). Difco Manual: Dehydrated Culture Media and Reagents for Microbiology. $10^{\text {th }}$ ed, Pub. Difco Laboratories, Detroit, Michigan, USA.

El-Adawy, T. A. (1997). Effect of sesame seed proteins supplementation on the nutritional, physical, chemical and sensory properties of wheat flour bread. Food Chem. 59: 7-14.

El-Amin, S. M., M. A. M. Hashash, A. M. Abdou, A. M. Saad, Abdel-Aziz, M. S. and A. S. Mohamed (2016). Antimicrobial and antioxidant activities of Psidium guajava leaves growing in Egypt. Der Pharmacia Lettre, 8 (12): 2733.

Fernandes, M. R. V., A. L. T. Dias, R. R. Carvalho, C. R. F. Souzaa and W. P. Oliveira (2014). Antioxidant and antimicrobial activities of Psidium guajava L. spray dried extracts. Industrial Crops and Products, 60: 3944.

Fischer, U. A., R. Carle and D. R. Kammerer (2011). Identification and quantification of phenolic compounds from pomegranate (Punica granatum L.) peel mesocarp, aril and differently produced juices by HPLC-DAD-ESI/ MSn. Food Chemistry, 127, pp. 807821

Hafez, A. A. (2012). Physico-chemical and sensory properties of cakes supplemented with different concentration of marjoram. Australian Journal of Basic and Applied Sciences, 6 (13): 463- 470.

Ibrahium, M. I., M. E. Abd El-Ghany and M. S. Ammar (2013). Effect of clove essential oil as antioxidant and antimicrobial agent on cake shelf life. World Journal of Dairy and Food Sciences, 8 (2): 140-146.

Jeyanthi, R. L., C. Seshiah and D. Sharmila (2016). Fortification of cupcakes with cereals and pulses. International Journal Novel Research of Life Science, 3(3):1-6

Khaki, M., M. A. Sahari and M. Barzegar (2012). Effects of chamomile (Matricaria chamomilla L.) essential oil on cake shelf life. Journal of Medicinal Plants, 11: 9-18.

Khalifa, I., H. Barakat, H. A. El-Mansy and S. A. Soliman (2015). Physicochemical, organolyptical and 
Eman A. Wahba, et al.,

microbiological characteristics of substituted cupcake by potato processing residues. Food and Nutrition Sciences, 6: 83-100.

Kordsardouei, H., M. Barzegar and M. A. Sahari (2013). Application of Zataria multiflora Boiss and Cinnamon zeylanicum essential oils as two natural preservatives in cake. Avicenna Journal of Phytomedicine, 3 (3): 238-247.

Kozłowska, M., A. Zbikowska, A. Szpicer and A. Poltorak (2019). Oxidative stability of lipid fractions of spongefat cakes after green tea extracts application. Journal of Food Science and Technology, 56 (5): 2628-2638.

Lu, T. M., C. C. Lee, J. L. Mau and S. D. Lin (2010). Quality and antioxidant property of green tea sponge cake. Food Chemistry,119, 1090-1095. https://doi.org/10.1016/j.foodchem.200 $\underline{9.08 .015}$

Mahmoud, K. F., M. A. Ibrahim, M. ElDemery, H. A. Shaaban, M. M. Kamil and N. A. Hegazy (2016). Nanoencapsulation efficiency of lemon and orange peels extracts on cake shelf life. American Journal of Food Technology,11 (3): 63-75.

Mahmoudi, L., H. Tavakoilpour, L. R. Nasiraie and A. K. Ashtari (2020). Ultrasonication and encapsulation of butcher broom (Ruscus hyrcanus L.) extract and its bioactive effects on qualitative properties, oxidative stability and shelf life of cake. Sustainable Chemistry and Pharmacy, 17: 1-9.

Nanditha, B. R., B. S. Jena and P. Prabhasankar (2009). Influence of natural antioxidants and their carrythrough property in biscuit processing. Journal of Agriculture and Food Science, 89: 288-98.

Sabouri, Z., M. Barzegar, M. A. Sahari and H. Badi (2012). Antioxidant and antimicrobial potential of Echinacea purpurea extract and its effect on extension of cake shelf life. Journal of Medicinal Plants, 11: 28-40.

Sandhir, R. A. Y., A. Sunkaria and N. Singhal (2015). Nano-antioxidants: An emerging strategy for intervention against neurodegenerative conditions. Neurochemistry International; 89: 209226.

Senanayake, C. M., C. H. Algama, R. L. Wimalasekara, W. N. N. Weerakoon, N. Jayathilaka and K. Seneviratne (2019). Improvement of oxidative stability and microbial shelf life of vanilla cake by coconut oil meal and sesame oil meal phenolic extracts. Journal of Food Quality, 1-8.

Senanayake, M. C., H. Hapugaswatta, N. Jayathilaka and $K$. N. Seneviratne (2018). Phenolic extracts of the leaves of Psidium guineense Sw. improve the shelf life of sunflower oil and baked cake and antioxidant status of Wistar rats. Journal of Food Biochemistry, 42: 1-10.

Sidwell, C. G., H. Salwin, M. Benca and J. H. Mitchell (1954). The use of thiobarbituric acid as a measure of fat oxidation. Journal of the American oil Chemists Society. (12), 603- 606.

Snedecor, G. W. and W. G. Cochran (1994). Statistical methods $\left(8^{\text {th }}\right.$ ed.). Calcutta, India: Oxford \& IBH Publishing Co. 
الاستفادة من بعض مستخلصات المواد النباتية لإطالة فترة صلاحية

الكب كيك أثناء التخزين

إيمان عبدالستار وهبة، طارق أحمد العدوي، أمل أحمد عاطف، علاء الدين السيد البلتاجي

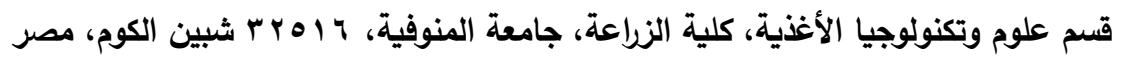

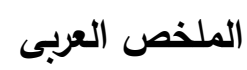

تم استخلاص المركبات الطبيعية النشطة بيولوجيا (مضادات الأكسدة ومضادات الميكروبات) من ثلاث مواد نباتية

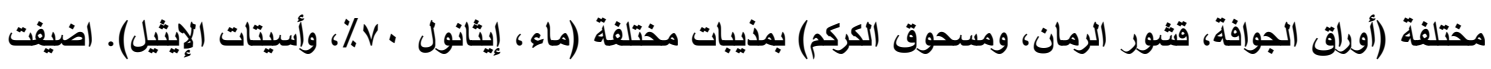

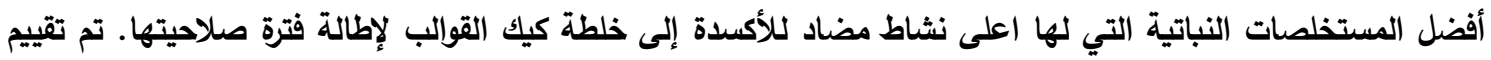

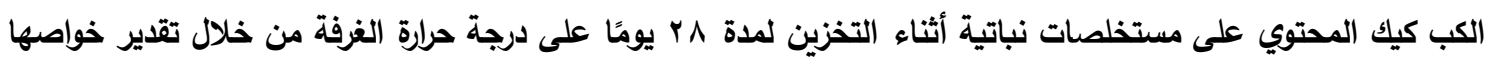

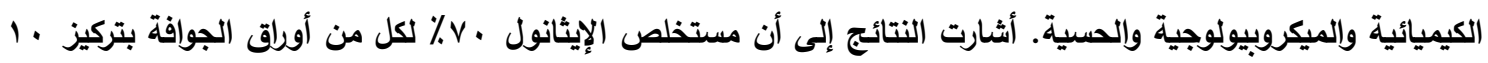

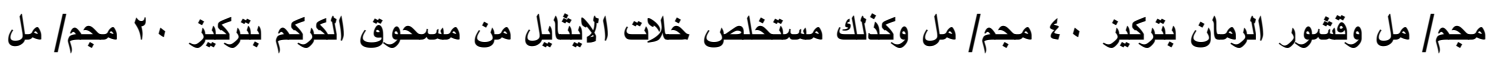

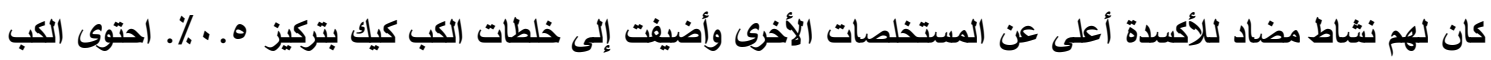

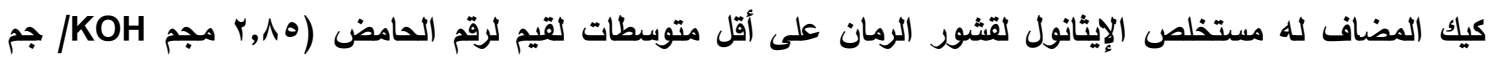

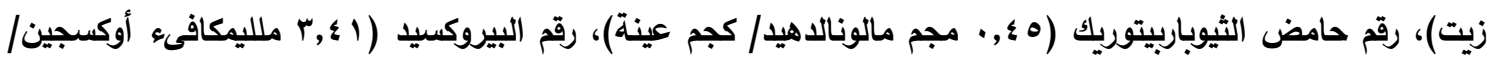

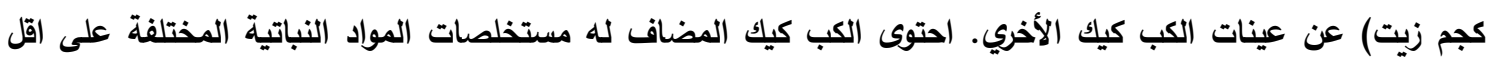
متوسطات لقيم العدد الكلي للبكتيريا وعلد بكتيريا القولون. سجل الكب كيك الاتب المحتوى على المستخلص الإيثانولى لقشور

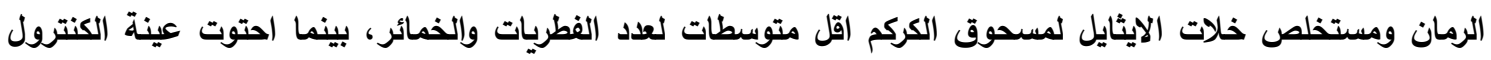

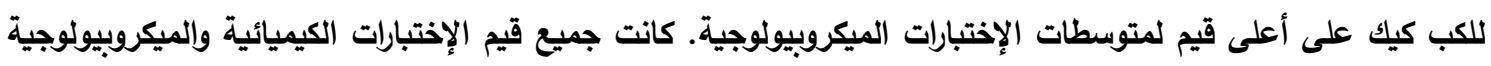

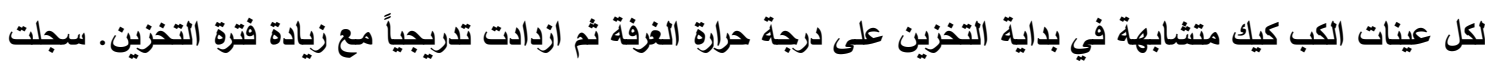

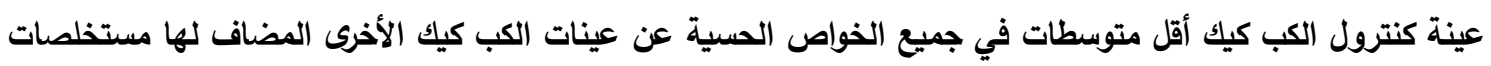

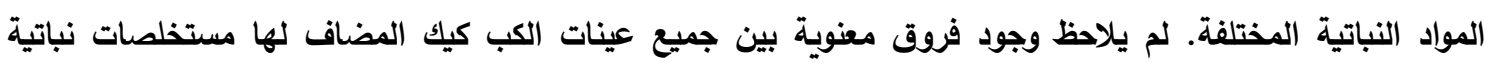

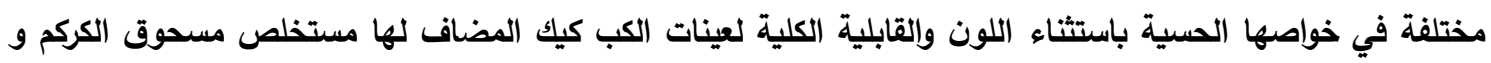
الالفا توكوفيرول. الكلمات الدالة: الكب كيك، مستخلصات نباتية، أورلق الجوافة، قشور الرمان، الكركم، العمر التخزيني، الخواص الكيميائية، التحليل الميكروبيولوجي والخواص الحسية.

السادة المحكمين

أ.د/ سمير يوسف السناط كلية الزراعة - جامعة كفر الثيخ

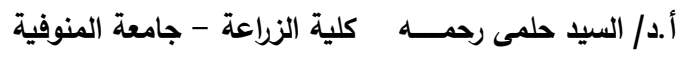

